\title{
FLORAL ONTOGENESIS AND EMBRYOGENESIS FEATURES OF THE RELIC WILD LAPERRINE'S OLIVE (OLEA EUROPAEA SSP LAPERRINEI) IN ARID CENTRAL SAHARA
}

\author{
LAHMISSI, A. ${ }^{1,2^{*}}-$ VERDEIL, J. L. ${ }^{3}-$ BOUGUEDOURA, N. ${ }^{1}$ \\ ${ }^{1}$ Research Laboratory of Arid Zones (LRZA), Faculty of Biological Sciences, University of \\ Sciences and Technology Houari Boumediene (USTHB), PO Box, 32 El Alia Bab-Ezzouar, \\ 16111 Algiers, Algeria \\ ${ }^{2}$ University Mouloud Mammeri, Faculty of Biological and Agronomical Sciences, Tizi-ouzou, \\ Algeria \\ ${ }^{3}$ International Center for Agronomic Research and Development, Montpellier, France \\ *Corresponding author \\ e-mail: lahmissiaamina@gmail.com; phone: +213-551-496-538; fax: +213-2163-9141 \\ (Received $13^{\text {th }}$ Nov 2019; accepted $12^{\text {th }}$ Feb 2020)
}

\begin{abstract}
Olea europaea subsp. laperrinei (Batt. \& Trabut) Cif., is an endemic species of Ahaggar (Hoggar) and Tassili N'ajjer in southern Algeria, with powerful adaptation against harsh conditions. Several genetic and phylogenetic studies have been done on this taxon, offering awareness on its reproductive methods and its use as a genetic resource of the cultivated olive, but no attention was given to the ontogenesis and zygotic embryogenesis for this centenary desert plant. This work is focuses particularly on the morphology of the flower followed by the analysis of the cytological and histological changes during early zygotic embryogenesis, with the aim to identify and characterize gametophytes playing a role in this process. The results of this investigation showed different types of flowers as well as imperfections in the female gametophyte that is often absent or without nuclei in this species. These particular observations could be considered as adaptation behaviour of this plant relic against arid conditions.
\end{abstract}

Keywords: Olea europaea subsp. laperrinei, cyto-histological study, genetic resource, male gametophyte, female gametophyte, embryos development

\section{Introduction}

The Laperrine's olive tree, (Olea europaea subsp. Laperrinei (Batt. \& Trabut) Cif.), is a relic taxon spread out across the central Saharan mountains (1400-2800 m altitude), considered as an endemic species from the Oleaceae family representing an important genetic resource due to its adaptation to arid conditions.

Note, that Olea europaea is a species composed of six subspecies with wild populations extended in large zones of south of Asia, Africa and southern Europe (Green, 2002).

Quézel (1965) has recognized a few individuals of (Olea europaea subsp. laperrinei) in Algerian Saharan areas. In contrast, the first inventories conducted by Baali-Cherif et al. (2007) indicated the presence of thousands of individuals in Hoggar and Tassili. In addition, it is found in granite massifs of Ahaggar Mountains (Tefedest) but rare at Tassili n'Ajjer and in Mouydir.

Besnard et al. (2007) and Anthelme et al. (2008) showed that this subspecies is distributed across fragmented habitats and locally exposed to extinction by the absence of the populations' regenerative capacities. These studies have reported that multicentennial individuals which mainly reproduce vegetatively can restore sexuality under 
favourable conditions. Recently, crosses between the Laperrine's olive and other olive diploid subspecies (subspp. cuspidata and europaea) have been reported.

Although, this plant species offers a plant matter for animals and prevent other plants disappearance, no natural regeneration was reported since several years (Maire, 1933; Quézel, 1978) causing its genetic diversity limit by the absence of fruits (self-incompatibility), due to the high separation of trees by high mountains reducing the pollen transportation and thus gene flow (Besnard et al., 2007).

Biological reproduction for this relic species is now becoming a priority, and hence its germplasm preservation is needed, among the ex situ methods available, the seed germination is considered the most efficient method (Benarar and Bouguedoura, 2003). Seeds are important starting materials for tree breeding and genetic improvement. Their use enables capturing the natural genetic variation (due to random mating or pollination). Indeed, several populations of this plant species identified by Baali-Cherif and Besnard (2005). These authors envisaged that through sexual hybridization, new and superior genotypes could be developed; they explained the possible sexual reproduction system role in genetic variation loss such as small populations could "turn-over" of the others causing strong genetic erosion and taxon's disappearance.

Therefore, this study reports for the first time a number of information about the reproductive biology by morphological and histological aspects of floral biology. The well knowledge of major steps could be helpful to understand how to prevent the production of abnormal flowers and seeds and enhance the genetic diversity of this important taxon considered as a green belt and rootstock of local varieties.

\section{Material and methods}

The present investigation was undertaken with the trees at 1400-2300 $\mathrm{m}$ of altitude of Ahaggar in Southern Algeria (Fig. 1), characterized by seasonal temperature and rain full regime variations (cold winter $15.40^{\circ} \mathrm{C}$ and $1.24 \mathrm{~mm}$; hot summer $26.6^{\circ} \mathrm{C}$ and $8.60 \mathrm{~mm}$ ).

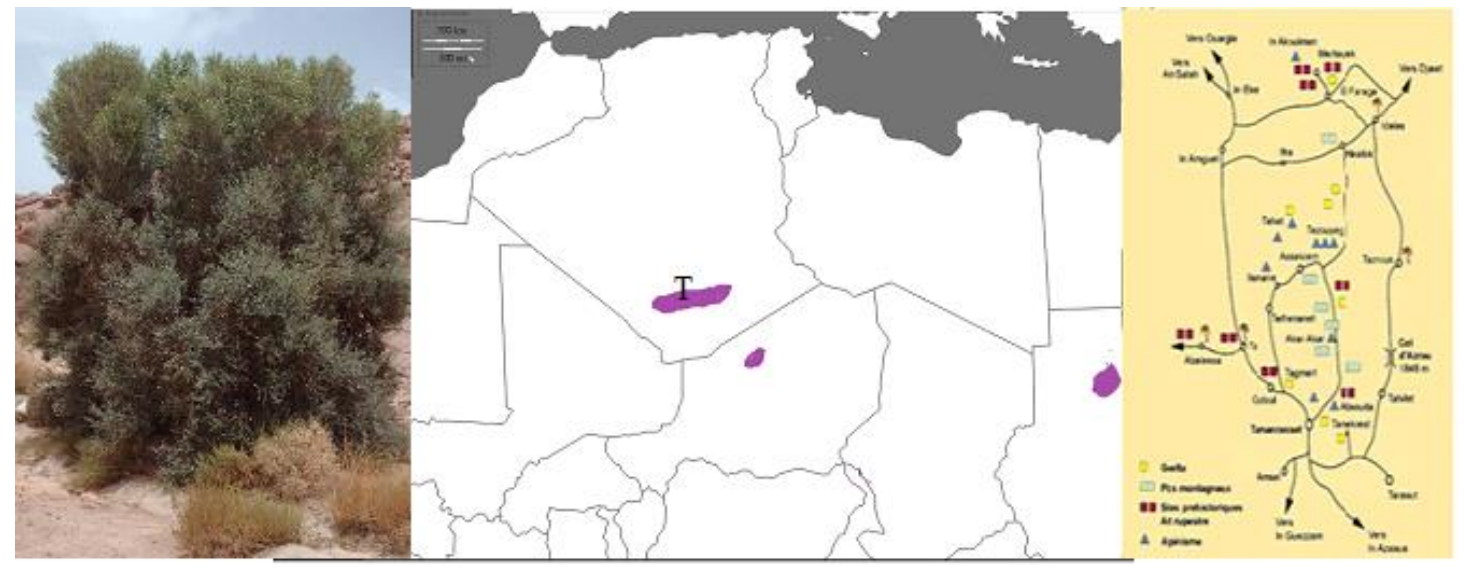

Figure 1. Natural distribution of Olea europaea ssp laperrinei in southern Algeria (T: Tamanrasset) with some sampling areas (Akar-akar and Tezouyeg) according to website (Algerian agency. Tazrouk stays.com)

Fresh plant parts (vegetative and floral buds, mature flowers) were collected from adult trees in flowering period for 3years (2013-2015) between March and June according to 
areas location (Table 1). The vegetative and reproductive organs were examined and compared.

Table 1. Location of sampling areas according to the altitude $(m)$

\begin{tabular}{c|c|c|c}
\hline $\begin{array}{c}\text { Local name of Sampling } \\
\text { areas }\end{array}$ & Altitude (m) & Latitude & $\begin{array}{c}\text { Individuals } \\
\text { number }\end{array}$ \\
\hline Aguellala & from 1400 to 1500 & $\begin{array}{r}22^{\circ} 38127 \mathrm{~N} \\
05^{\circ} 36724 \mathrm{E}\end{array}$ & 11 \\
\hline Ainergiouene & 1803 & $\begin{array}{r}22^{\circ} 11167 \mathrm{~N} \\
06^{\circ} 02874 \mathrm{E}\end{array}$ & 2 \\
\hline Akar-akar & from 1866 to 1885 & $\begin{array}{l}23^{\circ} 03306 \mathrm{~N} \\
05^{\circ} 42616 \mathrm{E}\end{array}$ & 7 \\
\hline Tagherra & 1693 & $\begin{array}{l}23^{\circ} 09692 \mathrm{~N} \\
06^{\circ} 01529 \mathrm{E}\end{array}$ & 5 \\
\hline Tezouyeg & from 2150 to 2331 & $\begin{array}{l}23^{\circ} 12593 \mathrm{~N} \\
05^{\circ} 42413 \mathrm{E}\end{array}$ & 6 \\
\hline
\end{tabular}

\section{Morphological and anatomical studies}

The morphological assessment was carried out by external aspects observation and measurement of fresh specimens. The organs were observed and photographs were taken by using Canon Power Shot A640 camera through the stereomicroscope StemiDV4 (Zeiss, Germany).

For the cyto-histological studies, the fresh samples were fixed in FAA fixator (Formaldehyde 37\% (1 volume)-glacial acetic acid (1 volume)-Alcohol 70\% (8 volume) or in Glutaraldehyde-Paraformaldhehyde-Caffeine fixator (Glutaraldehyde (25\%) $4 \mathrm{ml}$ phosphate buffer $\mathrm{pH} 7.2-50 \mathrm{ml}$ - paraformaldehyde (10\%) $20 \mathrm{ml}$ and caffeine $1 \% 1 \mathrm{~g}$ ) (Schwendiman et al., 1990). The specimens were dehydrated and embedded in paraffin or in resin (Reichert-Jung Historesin). Thin sections of 2.5-5 $\mu \mathrm{m}$ were cut with microtome (Leica, Germany) and stained by Periodic Acid Schiff (PAS)-Naphthol Blue Black (NBB) (Feder and O'Brien, 1968; Fisher, 1968). Microphotographs were obtained using Canon camera, Power Shot A640 and Q-imaging Retiga 2000R camera combined with DM4500 microscope (Leica, Germany).

For transmission electron microscopy, floral parts were prefixed in $4 \%$ glutaraldehyde (1 volume)-cacodylate buffer $\mathrm{pH} 7.4$ at $0.4 \mathrm{M}$ (1 volume) and were fixed in $2 \%$ osmium tetroxide (1 volume)-cacodylate buffer $\mathrm{pH} 7.4$ at $0.4 \mathrm{M}$ (1 volume) - (Pottu-Boumendil, 1989 ) and then, embedded in Epoxy resin (Fluka). Ultra-thin sections of $0.01 \mu \mathrm{m}$ were carried out with EM UC7 microtome (Leica, Germany) stained with positive contrast (2\% uranyl acetate then lead citrate) (Pottu-Boumendil, 1989). Observations and microphotographs were made using the 1200EXII microscope (Jeol, Japan).

\section{Results}

Through sexual reproduction, Laperrine's olive tree individuals form four different types of flowers varying between trees, areas and sampling year (Table 2). 
Table 2. Variation rate of different flowers

\begin{tabular}{c|c|c|c|c|c}
\hline \multirow{2}{*}{ Sampling areas } & \multirow{2}{*}{ Year } & \multicolumn{4}{|c}{ Percentage of flower types (\%) } \\
\cline { 3 - 6 } & & Type1 & Type2 & Type3 & Type4 \\
\hline \multirow{3}{*}{ Aguellala } & 2013 & 75 & 15 & 10 & 0 \\
& 2014 & 80 & 10 & 10 & 0 \\
& 2015 & 80 & 15 & 5 & 0 \\
\hline \multirow{3}{*}{ Ainergiouene } & 2013 & 85 & 10 & 5 & 0 \\
& 2014 & 80 & 15 & 5 & 10 \\
\hline
\end{tabular}

The flower (Fig. 2A) with fully developed parts: 4 sepals, 4 petals, 2 stamen (type 1) is the most frequent, following by flowers with less prominent and necrotic stigmas (type 2 ), male flowers with rudimentary and very insignificant pistils (type 3 ) and flowers with 3 stamen instead 2 (type 4) (Fig. 3A and B).

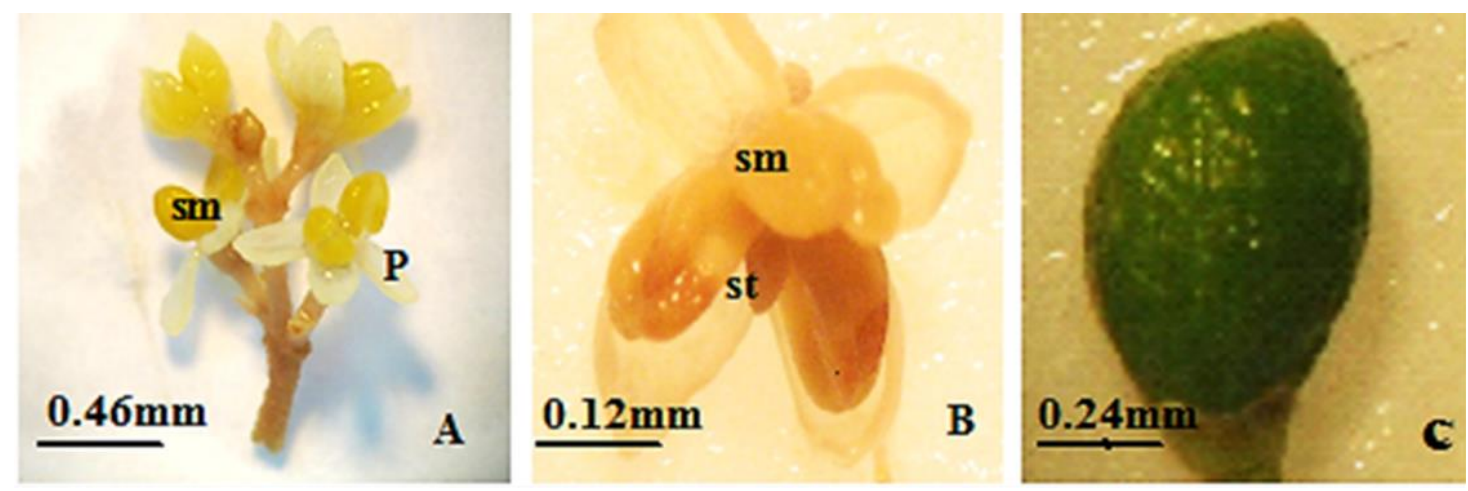

Figure 2. Inflorescence (A), flower (B) and fruit (C) of Olea europaea ssp. laperrinei. p: petal, sm: staminate, st: stigma

\section{Mature flower structure}

The flower of the Laperrine's olive tree is hermaphrodite or male flowers of $4.5 \mathrm{~mm}$ height, each with 4 greenish gamosepals, 4 whitish petals, 2 yellowish stamens with a longitudinal introrsely dehiscence and pistil formed of an ovary of two fused carpels bi-ovuled each, a style and of a two-lobbed dome shaped stigma. The pistil and the stamens have the same length (about $2.5 \mathrm{~mm})$, stigma $(1 \mathrm{~mm})$, the style $(0.5 \mathrm{~mm})$ and ovary diameter (1-1.2 $\mathrm{mm})$.

\section{Flower ontogenesis: morphology and histology}

The vegetative bud's foliar initiation is decussate corresponding to Laperrine's olive tree's phyllotaxis. The observation of axillary vegetative buds showed that previous year's twigs initiate floral buds in comparison to those of actual year which do not flowering. 

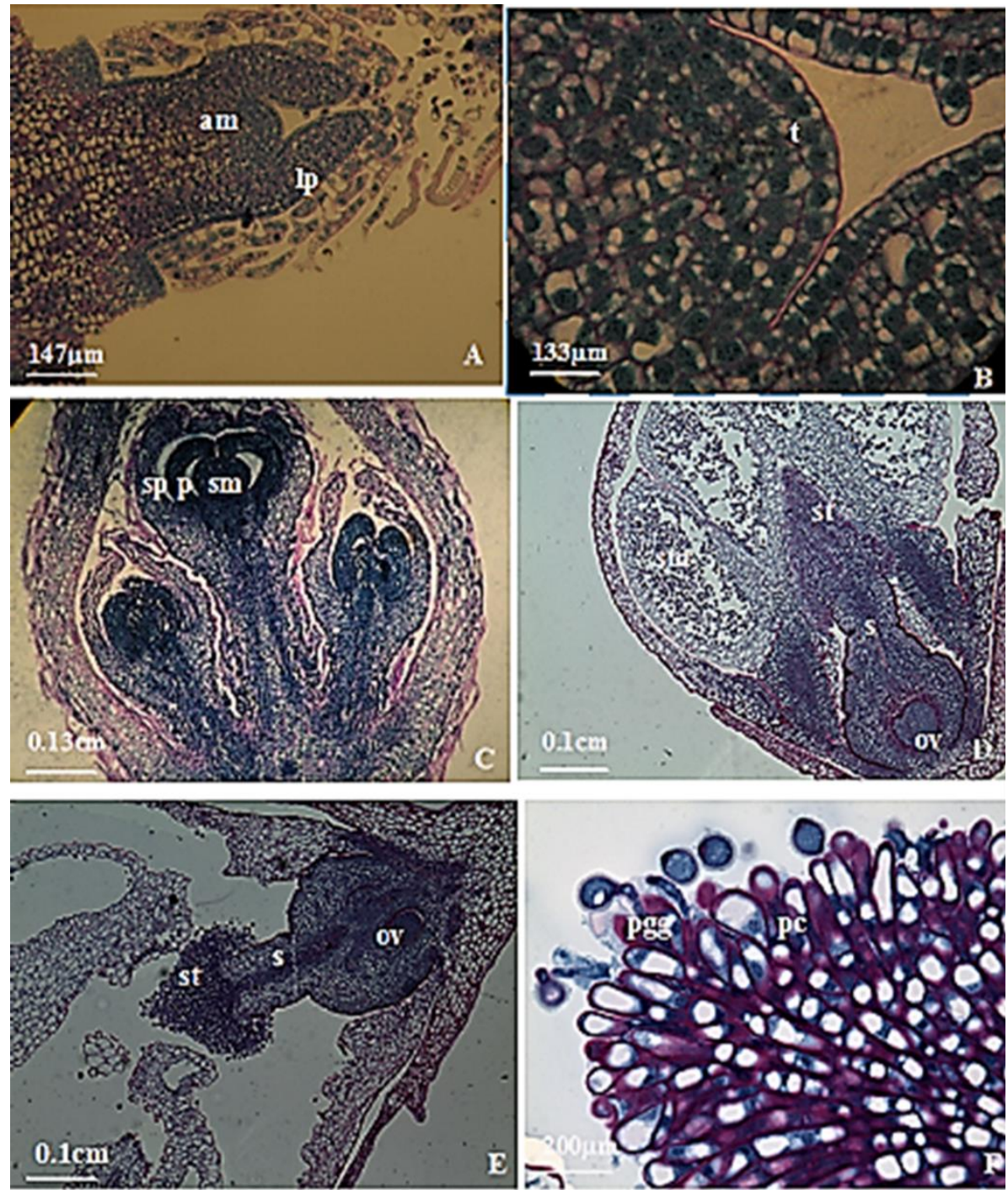

Figure 3. Histological structures of vegetative and floral buds. A. Vegetative bud. B. Vegetative apical meristem. C. Youngflower bud. D. mature flower bud. E. Ovary. F. Stigma details. am: apical meristem, lp: leaf primordium, ov: ovary, p: petal,pc: papillar cells, pg: pollen grain germination, s:style, sm: stamen.,sp: sepal, st: stigma, t: tunica

The morphological analysis of buds before flowering showed that the growth of vegetative twigs starts between March and April depending on the zone's altitude and temperature. The vegetative apical meristem (dome) is wide showing three heterogeneous zones; apical zone formed by tunica of one or two layers; lateral zone on the flanks enabling foliar initiation and the medullary zone located under the apical zone with lined up cells (Fig. $3 A$ and $B$ ).

According to the histological study, it appears that the future flower bud's apical dome is more prominent $(650 \mu \mathrm{m})$ than that of the vegetative bud $(292,6 \mu \mathrm{m})$ covered by external bracts, formed by homogeneous structure of strongly meristematic cells called floral primordium (Fig. 3C), which develops into a flower bud (Fig. 3D).

Three types of flower buds were observed with variations in pistil; first type with twolobed prominent stigma (Fig. 3D); the second type with less prominent and necrotic stigma (Fig. 4A) and the third type with a rudimentary pistil (Fig. 4B). 


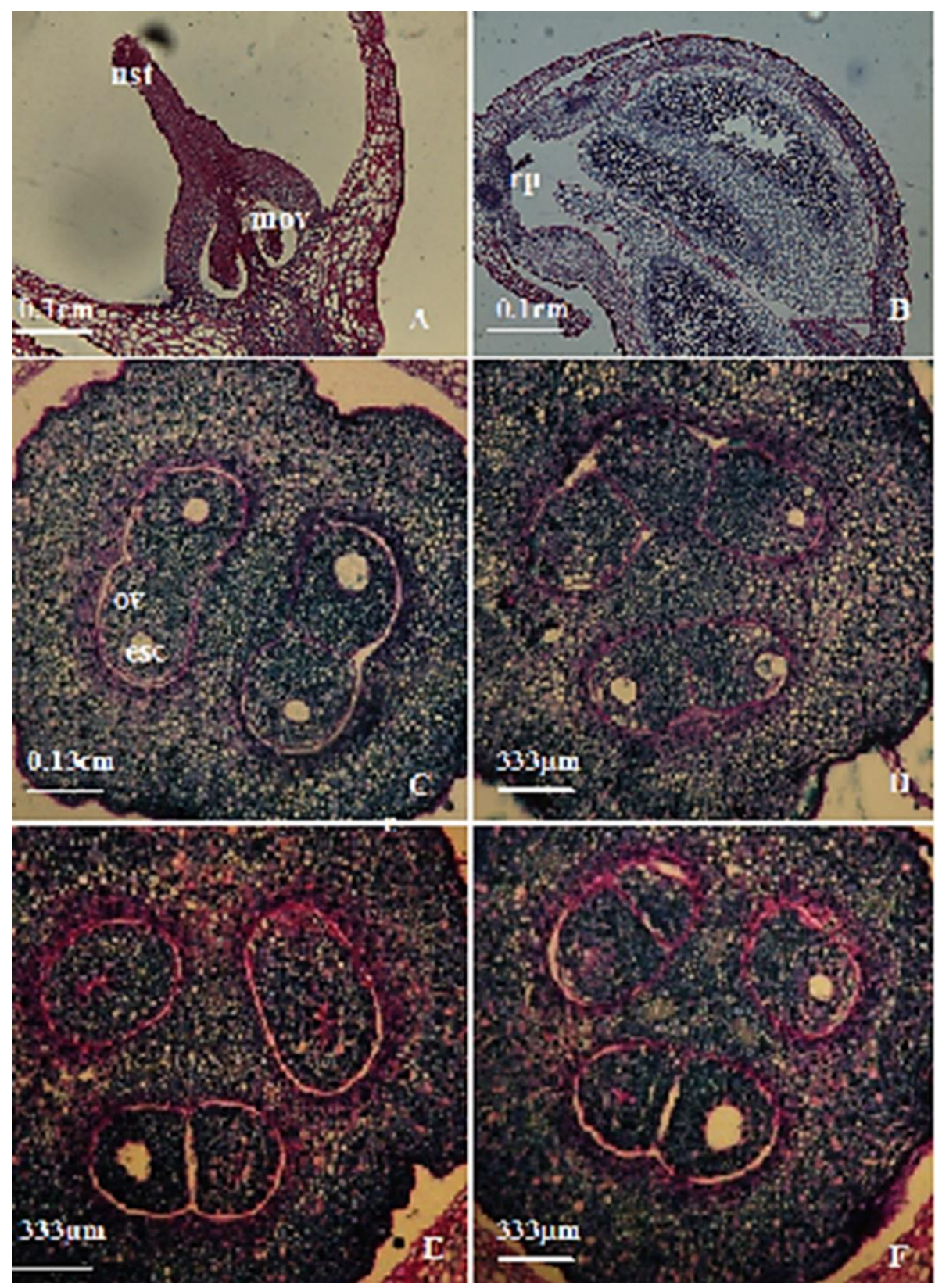

Figure 4. Different abnormalities of ovarian development. A, B. Abnormal Pistil C. Ovary (2 carpels and 4 ovules). D. Abnormal ovary ( 2 carpels and 5 ovules). E. Abnormal ovary ( 3 carpels and 4 ovules). F. Abnormal ovary (3 carpels and 5 ovules). c: carpel, es: embryo sac, mov: malformed ovule, nst: necrotic stigma, ov: ovule, rp: rudimentary pistil, nst: necrotic stigma

\section{Androecium and male gametophyte}

Anthers are composed of four pollen locules of different shape and size. Those with only two or three locules observed are due to their incomplete development.

From outside to inside, each anther contains an epidermis with wide cells, a mechanical layer, a layer of transitional cells, a medullar layer and a tapetum of two to three layers of protein-rich cells with a central big nucleus remembering meristematic cells (Fig. 5A). 

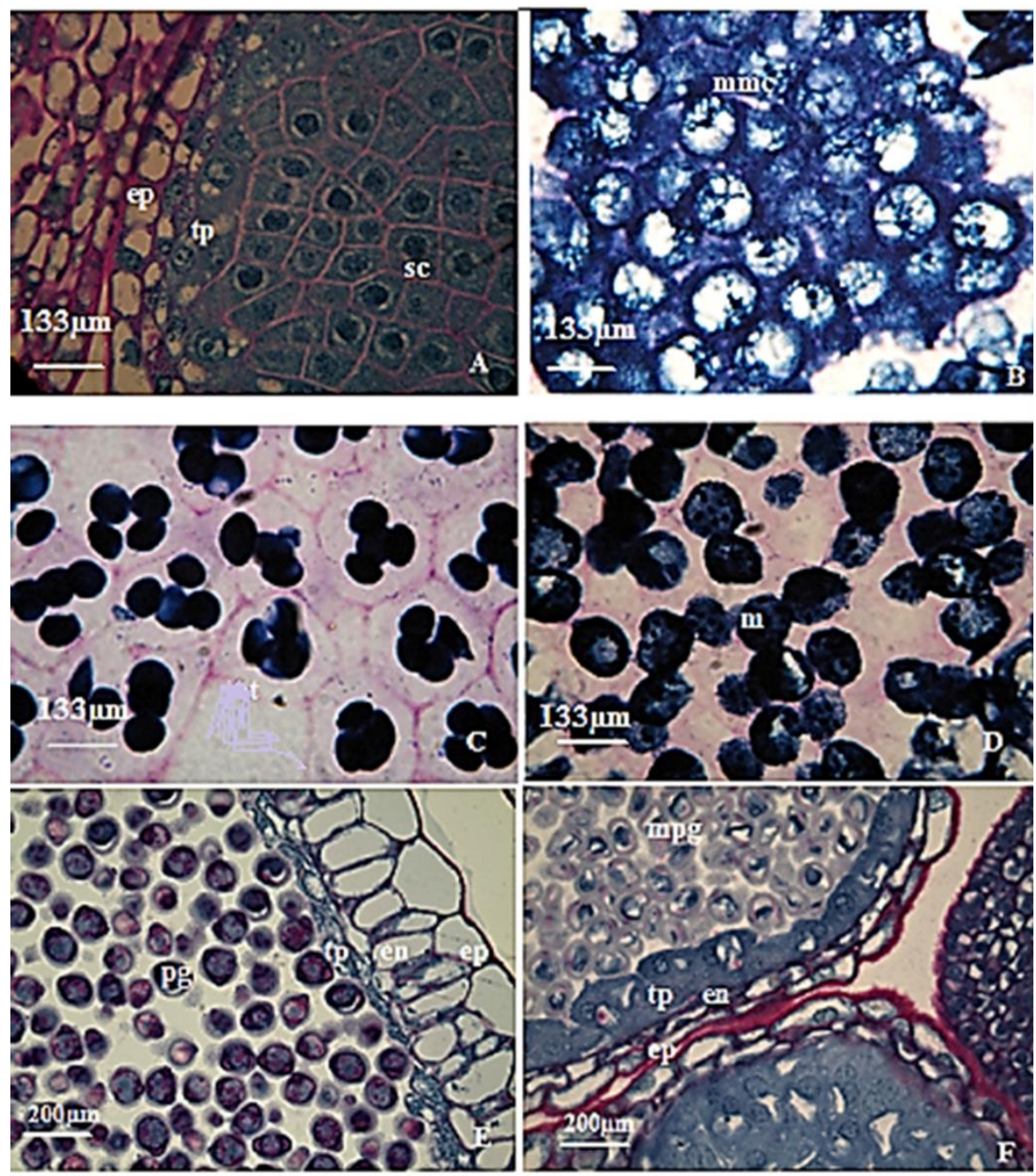

Figure 5. Stages of male gametophyte development: A. Stamen and sporogen tissues.B. Mother cells. C. Tetrads. D. Microspores. E. Different stamen layers with fertile pollen. F. Different stamen layers with malformed pollen. en: endothecium,ep: epidermis,m: microspore, mmc: mother cell of microspore, mpg: malformed pollen grains, pg: pollen grain, sc: sporogenous tissue, $t$ : tetrad, ta: tapetum

The medullar layer begins to degenerate in the early stages of meiosis of microsporocytes. Indeed, the tapetum degeneration follows the first uninucleate microspores formation and continues until maturation. The sporogenous tissue is initially formed by polygonal-shaped cells (Fig. 5B), which differentiate into mother cells of spores forming tetrads surrounded by callose as tetrahedral type or rarely rhomboidal after meiosis (Fig. 5C).

The Electronic microscopy observation shows that mature pollen grains are bicellular and rich in starch at dehiscence time (Fig. 5E), the reproductive cell, previously found against the vegetative cell's wall, are in the middle of cells (Fig. 6A and B).

Triporate pollen grains presenting TEM images of apertures in equidistant positions composed of ecto aperture covered by a cross-linked tectum and of the endo aperture, these pollen grains can be observed onto the stigma surface and the ovary is fertilised 
before the dehiscence of this flower's stamens. This situation induces the stigma's responsiveness before the stamens maturation and confirms the allogamy of the species.

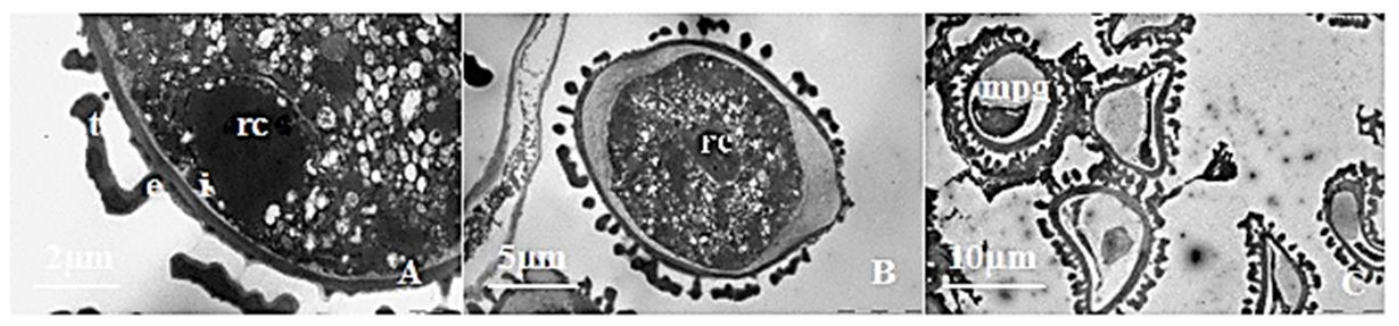

Figure 6. Transmission electron micrographs of cross-sections through pollen grain during developmental stages. A. Non detached reproductive cell. B. Bicellular pollengrain, $C$. Malformed pollen grains, $e$ : exina, $i$ : intina, mgp: malformed pollenrc: reproductive cell, $t$ : tectum

The pollen locule can contain pollen grains showing a degeneration structure by deformation, cells are mostly empty formed of a tectum, exine, intine and a cytoplasm (Figs. $5 F$ and $6 C$ ). This degeneration is only noted at pollen grain stage in $30 \%$ of flower buds observed.

\section{Ovary and female gametophyte}

The superior ovary is most commonly composed of two unilocular carpels, each one contains two anatropous ovules (Fig. 4C), and its epidermis contains elongate cells covered by a large polysaccharide layer.

Underneath the epidermis exists a layer of cells of different sizes with large active nuclei rich in proteins.

The two carpels reach maturity at the same time containing four ovules that will have a different development: three ovules decline and only one ovule will continue its structuration. Ovaries with three carpels or carpels with three ovules seldom seen are considered as anomalies (Fig. 4 D, E and F).

The narrower style covered by a polysaccharide layer (mucilage) is composed by an external epidermis and an intermediate tissue, organised into several cell layers with large vacuoles and of a vascular tissue as well as a transmission tissue that passes over its entire length.

The style widens into a bifid stigma sometimes mono or trifid whose surface is comprised of papilla cells with large vacuoles and covered by a layer of extracellular exudates of carbohydrate nature. The stigmas internal cells are non-papillary and surrounded by an accumulating substance in the intercellular area.

Unitegumented ovules with a very short funiculus, whose micropyle is narrow, develop at the same time but cases exist in which one or two of the four ovules are smaller (Fig. 4C, D, E and F).

For hermaphrodite flowers, cyto-histological study by photonic and electron microscopy has most often shown the absence of embryo sacs on a number of sliced ovules (Table 3). In some ovules, the embryo sac is involute; and in some rare cases, we could observe a typical embryo sac. This mature sac is of bisporic Allium type, which characterises the Olea type, therefore eight nuclei (Altamura et al., 1982). The nuclei located in the different levels of the sac are non-observable at the same time. The mature 
embryo sac's cavity, narrow and fusiform, contains two synergids and one egg cell on the micropyle's side, two polar nuclei and three antipodal cells on the side of the chalaza (Fig. 7 A, B, C and D).

Table 3. Frequencies of different embryo sacs types in hermaphrodite flowers

\begin{tabular}{c|c|c|c}
\hline Sampling areas & Year & $\begin{array}{c}\text { Percentage of ovule with typical } \\
\text { embryo sac per ovary }\end{array}$ & $\begin{array}{c}\text { Percentage of ovule with absent or } \\
\text { empty embryo sac per ovary }\end{array}$ \\
\hline \multirow{3}{*}{ Aguellala } & 2013 & 8 & 92 \\
& 2014 & 11 & 89 \\
& 2015 & 10 & 90 \\
\hline \multirow{3}{*}{ Ainergiouene } & 2013 & 10 & 90 \\
& 2014 & 14 & 86 \\
& 2015 & 12 & 88 \\
\hline
\end{tabular}

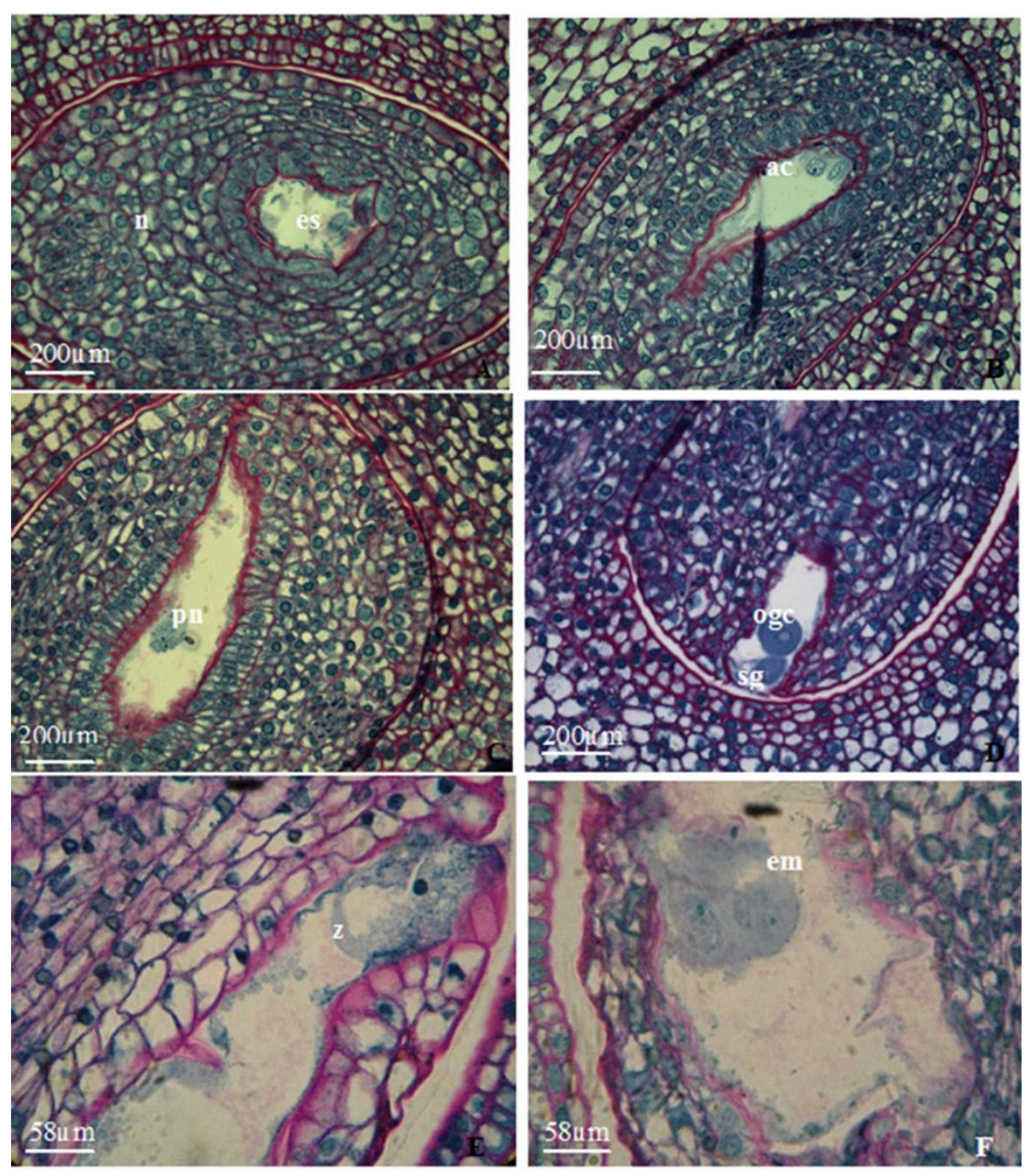

Figure 7. Female gametophyte and embryogenesis. A. ovule with embryo sac cavity. B. Three antipodal cells. C. Two polar nuclei. D. Synergid and egg cell. E. Fertilised embryo sac: zygote. F. Young embryo (proembryo). ac: antipodal cells, egc: egg cell, em: embryo, es: embryo sac, n: nucellus, pn: polar nuclei, sg: synergids, z: zygote 
For flowers with a necrotic stigma, the embryo sac is deformed, empty or lacking, thus, the pistil's development is interrupted before the formation of the embryo sac. For male flowers, no embryo sac can be observed and the ovary kept rudimentary (Fig. 4 A, B).

\section{Fertilisation and fruit formation}

At fertilisation, only one ovule of four is fertilised. The ovules of the sterile carpel degenerate while those of the fertile carpel experience two different evolutions: one ovule is fertilised to become the seed and the other degenerate after long period comparing to sterile carpel's ovules. Note that, in the fruit development, it is possible to observe the remains of the locule surrounding the fertile carpel's non-fertilised ovule.

The ovule's fertilisation leads to the formation of the large spherical shaped zygote at the same time of beginnings of nuclear endosperm by central cells (Fig. 7 E).

An embryo is observed after this fertilisation while synergids and antipodal cells degenerate (Fig. 7 F).

\section{Discussion}

\section{Floral anatomy}

The study of Laperrine's olive tree showed that at flowering time, four types of flowers are formed on each tree; the normal hermaphrodite flower, the necrotic pistil flower, the male flower and three stamens flower. The first and the second types were observed by Reale et al. (2009), the third by Breton and Bervillé (2013) on the cultivated olive tree.

After the period of vegetative rest (autumn and winter), the buds have the same morphological structure and sprout from March to give new twigs and flowers for the next year. This seems to correspond to the bud burst and flowering period of the cultivated olive tree. Indeed, Aiachi-Mezghani et al. (2008) confirmed that for the cultivated olive tree, vegetative growth is more or less continuous from spring up to autumn. The typical structure of the vegetative apex is in line with angiosperms (Camort and Boué, 1997; Vallade, 1999) by zonation of the meristematic territory.

Floral differentiation begins at the end of March in some stations and can be delay until June in the others. Indeed, this differentiation depends on the altitude and temperature. In tropical zones, the flowering of Laperrine's olive trees takes place in spring like most olive cultivars in California (Fabbri and Benelli, 2000) due to the endogenous hormones variation (Badr Sayed et al., 1970). On the other hand, in Portugal, the Galega and Verdea cultivars flower as soon as February (Hartmann, 1951).

According to Malik and Pérez (2011), the low temperatures of winter are development of Olea europaea subsp. lapperenei follows the same steps of development as Olea europaea subsp. europaea (Yurukova-Grancharova et al., 2011), Syringa vulgaris (Jedrzejuk and Wladyslaw, 2005) and Fraxinux angustifolia (Rodriguez-Rajo et al., 2010).

After maturation, tetrads give bicellular pollen grains, rich in starch with dehiscence time similar on the cultivated olive tree (Serrano et al., 2010). Anthers' tissue layers develop the same as on cultivated olive trees (Yurukova-Grancharova et al., 2011). However, the difference observed concerns the tapetum cells that at tetrad stage are either mononuclear or binuclear like for Colobanthus quitensis (Kunth) Bartl (Gielwanowska et al., 2007). 
Yurukova-Grancharova et al. (2011) observed that cell nuclei of the tapetum are divided and become binuclear, rarely tetra nuclear in 'Regalis', 'Chalkidis' and 'Pomiformis' cultivars of the cultivated olive tree compared to Pomiformis cultivar with 4 to 6 nuclei in tapetal cells.

Note that, Fernandez and Rodriguez-Garcia $(1989,1995)$ reported that Laperrine's olive pollen grains structure is similar to that of complex Olea.

Our results showed well-formed pollen grains and others with incomplete development or malformed (coloured in blue) indicating the absence of carbohydrates. Cuevas and Polito (2004) and Reale et al. (2006) have observed malformed pollen grains in Olea europaea subsp. europaea. According to Gielwanowscka et al. (2007), the pollen malformation can be a response to thermal or osmotic stress.

The allogamy and self-incompatibility in Olea europaea subsp. laperrinei confirmed by Besnard et al. (2007) could explain the low fruit production because the long distance separation between populations of Olea europaea subsp. laperrinei. Serrano et al. (2008) reported a high level of self-incompatibility in cultivated olive tree.

For the female gametophyte, the histological study often showed the absence of an embryo sac in ovules or existed but less developed (no nuclei), these cases are pointed out by Rapoport and Rallo (1991) for the cultivated olive tree, for the 'Manzanillo' cultivar and by Martin et al. (2006) for the 'Morisa' cultivar.

The mature embryo sac was observed only in hermaphrodite flowers belonging to Allium type of the Olea gender (Altamura et al., 1982; Yurukova-Grancharova et al., 2011) with eight-nucleate embryo sac.

For the flowers with necrotic stigmas, the embryo sac either was absent or is limited to its wall. These types of flowers and embryo sacs also exist in the cultivated olive tree (Cuevas and Polito, 2004; Martin et al., 2006; Reale et al., 2009). The proportion of each type depends of the tree genetics and climate conditions (Loussert and Brousse, 1978; Lavee et al., 1996). Indeed, according to these authors, the nutritional deficiency increases the pistil abscission leading to the formation of male flowers. For the Laperrine's olive tree, starch reserves are observed in different tissues of hermaphrodite flowers whereas no reserve is noted in the gynoecium of the necrotic pistil flowers.

Reale et al. (2006) made the same observations on the cultivated olive tree. It appears that, the carbohydrates are needed compounds from the flower initiation (Altamura et al., 1982) up to the complete differentiation of all floral organs (Rodrigo et al., 2000).

\section{Abortion cases}

Concerning the different abortion cases observed in different flowers studied, our results remind those obtained by Extremera (1985). This author specifies that the formation of ovules with malformed embryo sacs characterize Swan Hill cultivar not producing fruits; these structures can cause abscission of hermaphrodite flowers because the malformed embryo sac cannot be fertilised. This hypothesis can explain the substantial flowers drop for the Laperrine's olive tree by the higher rate of malformed embryo sacs within hermaphrodite flowers.

The production of male flowers following abortion of the olive tree's pistil is subject to genetic regulation and takes place one month before flowering (Reale et al., 2009). The lack of nutrients gives priority to pollen, thus to the production of male flowers (Cuevas and Polito, 2004). 
In different non-grazing areas, the Laperrine's olive trees show abundant flowering with a high percentage of hermaphrodite flowers while the flower drop was significant and the olive production is low.

According to Breton and Bervillé (2013), the cultivated olive tree's fruit production is low when there is no synchronisation between responsiveness of pistils and pollination regardless of the number of hermaphrodite flowers. Indeed, the percentage of hermaphrodite flowers varies from $95 \%$ for the Lucques cultivar to $5 \%$ for the Salonenque cultivar (Ouksili, 1983) whereas for the oleaste, this percentage reaches $100 \%$ or $0 \%$ (Hannachi and Marzouk, 2012). For Olea europaea subsp cuspidata, the vegetative twigs from one year before could have different proportions of male and hermaphrodite flowers (Mukonyi et al., 2012).

In the previous studies of Cuevas and Polito (2004) and Yurukova-Grancharova (2011), the overproduction of flowers with a high level of imperfect flowers and the suppression of fruit constitute a reproduction strategy for olive trees. Indeed, induced abortion of the grains before sclerification of the nuclear (endocarp), about 7 or 8 weeks after complete flower formation, improves or increases the following flowering (Stephenson, 1981).

Abortion is an important phenomenon that allows the tree to control its fruit production according to the availability of nutrient inputs like those that it showed with vines (Lebon et al., 2004).

According to Argenson et al. (1999), there are critical periods for the olive tree during flowering that can have an impact on the potential of fruit-production. Thus, a water or nutrient stress, arising between outbreak and six weeks before the anthesis, reduces the number of flowers per inflorescence and increased ovule abortion.

The overproduction of flowers allows the control of quantity and quality of fruits that depend on environmental conditions and availability of nutrients like it is shown with citrus where only $2 \%$ of flowers make fruits (Troncoso et al., 1978). The most anomalies and abortion of Olea lapperenei reproductive organs (flowers and fruits) summarised in this investigation could be explained by the advanced age of the trees or by the arid climate conditions (Loussert and Brousse, 1978; Besnard et al., 2012).

\section{Conclusion}

This study clearly showed many morphological and reproductive characters of the Laperrine's olive tree summarizing different types of flowers on the same tree with several abortion cases in both male and female gametophytes. All of these features indicate that this woody tree developed reproductive traits to drought tolerance and high longevity.

The absence of regeneration of centenarian's olive tree would be due to the random flowering and fruit drop before ripening. This can be explained by the not fully developed pollen grain production but self-incompatible for sexual reproduction or by malformed sterile pollen grains.

Even if, the female gametophyte, mature and typical, is also capable to conduct the sexual reproduction, the arid conditions cause earlier abortion of flowers and fruits. The results suggest that the well knowledge of flower development and reproduction will be helpful to the conservation of this tree in its natural ecosystem. The involvement of both user cuttings and seed germination trials are suggested. Also, the use of biotechnologybased techniques is needed. 
Acknowledgments. The authors acknowledge the General Direction of Scientific Research and Technological Development (DGRSDT) and the High Ministry of Research and Study (MESRS), Algeria for supporting this study. The authors also extend their thanks to the University Mouloud Mammeri, Faculty of Biological and Agronomical Sciences Tizi-Ouzou for providing the histological training in CIRADMontpellier and to Mr. Abdelaoui Mohamed Salah (head of INRF, Tamanrasset) for his help in collecting plant material.

\section{REFERENCES}

[1] Aichi-Mezghani, M., Ben El Hadj, S., Labidi, F., Jebari, A. (2008): Structure of the vegetative bud and relation with the result of growth in the olive tree (Olea europaea L.): characterization of winter and summer preformation. - Biotechnology, Agronomy, Society and Environment 12(3): 28-41.

[2] Altamura, B. M., Pasqua, G., Mazzolani, G. (1982): Development of the female gametophyte in Olea europaea L. - Annals of Botany 40: 111-117.

[3] Anthelme, F., Abdoulkader, A., Besnard, G. (2008): Distribution, shape and clonal growth of the rare endemic tree Olea europaea subsp.laperrinei (Oleaceae) in the Saharan mountains of Niger. - Plant Ecology 198: 73-87. DOI 10, 1007/s11258-007-9386-6.

[4] Argenson, C., Régis, S., Jourdain, J. M., Vaysse, P. (1999): The olive tree, monography. Paris, international technical center for fruit and vegetables; Ctifl. 204p. (in French).

[5] Baali-Cherif, D., Besnard, G. (2005): High genetic diversity and clonal growth in relict populations of Olea europaea subsp.laperrinei (Oleaceae) from Hoggar, Algeria. - Annals of Botany 96: 823-830.

[6] Baali-Cherif, D., Bouguedoura, N., Besnaed, G., Bouhired, L. (2007): Study of populations of Laperrine olive (Olea europaea subsp., Laperrinei Batt.and Trab.) of Algerian central Sahara (Hoggar and Tassili): Biological aspects and molecular characterization. - Annals of the National Agronomic Institute (Algiers) 28(1-2): 35-71.

[7] Badr Sayed, A., Hartmann, H. T., Martin, G. C. (1970): Endogenous gibberellins and inhibitors in relation to flower induction and inflorescence development in the olive. - Plant Physiology 46: 674-679.

[8] Benarar, D., Bouguedoura, N. (2003): Germination test of the Laperrine olive tree (Olea europaea ssp laperrinei Batt. and Trab.). - The Algerian forest 5: 15-18. (in French).

[9] Besnard, G., Christin, P. A., Baali-Cherif, D., Bouguedoura, N., Anthelme, F. (2007): Spatial genetic structure in the Laperrine's olive (Olea europaea subsp. laperrinei), a long living tree from the central Saharan mountains. - Heredity 99: 649-657.

[10] Besnard, G., Anthelme, F., Baali-Cherif, D. (2012): The Laperrine's olive tree (Oleaceae):A wild genetic resource of the cultivated olive and a model species for studying the biogeography of the Saharan Mountains. - Acta Botanica Gallica 159(3): 319-629.

[11] Breton, C., Bervillé, A. (2013): From the olive flower to the drupe: Flower types, pollination, self and inter-compatibility. - In: Breton, C., Bervillé, A. (eds.) The Mediterranean Genetic Code-Grapevine and Olive. Quae, Versailles. Http// dx.doi.org/10.5772/55312.

[12] Camfort, H., Boué, H. (1997): Reproduction and biology of higher plants: bryophytes, pteridophytes, Spermaphytes. - Second edition Doin. 436p. (in French).

[13] Cuevas, J., Polito, V. S. (2004): The role of staminate flowers in the breeding system of Olea europaea (Oleaceae): an andromonoecious, wind-pollinated taxon. - Annals of Botany 93: 547-553.

[14] Extremera, G. (1985): Development of the embryo sac in two olive cultivars (Oleaeuropaea L.). - Bachelor's thesis, Faculty of Sciences. Univ. De Córdoba, Córdoba, Spain. (In Spanish).

[15] Fabbri, A., Benelli, C. (2000): Flower bud induction and differentiation in olive. - Journal of Horticultural Science and Biotechnology 75(2): 131-141. 
[16] Feder, N., O'Brien, T. P. (1968): Plant microtechnique: sections for light microscopy. American Journal of Botany 55: 123-142.

[17] Fernandez, M. C., Rodriguez-Garcia, M. I. (1989): Developmental changes in the aperture during pollen grain ontogeny in Olea europaea L. - New Phytology 111(4): 717-723.

[18] Fernandez, M. C., Rodriguez-Garcia, M. I. (1995): Pollen grain apertures in Oleaeuropaea L. (Oleaceae). - Revew of Palaeobotany and Palynology 85: 99-109.

[19] Fisher, D. B. (1968): Protein staining of ribonnedepon sections for light microscopy. Histochimie 16: 90-92.

[20] Gielwanowska, I., Bochenek, A., Szczuka, E. (2007): Development of the pollen in the Antarctic flowering plant Colobanthus quitensis (Kunth). - Acta Agrobotanica 60(2): 3-8.

[21] Green, P. S. (2002): A revision of Olea europaea L. (Oleaceae). - Kew Bulletin 57(1): 91140.

[22] Hannachi, H., Marzouk, S. (2012): Flowering in the wild olive (Olea europaea L.) tree (oleaster): phenology, flower abnormalities and fruit set. Traits for breeding the olive. African Journal of Biotechnology 11: 8142-8148.

[23] Hartmann, H. T. (1951): Time of floral differentiation of the olive in California. - Botanical Gazette 112(3): 323-327.

[24] Jedrzejuk, A., Wladyslaw, S. (2005): Development of flower organs in common Lilac (Syringa vulgaris L) cv. Mme Florent Stepman. - Acta Biologica Cracoviensia, Series Botanica 47(2): 41-52.

[25] Lavee, S., Rallo, L., Rapoport, H. F., Troncoso, A. (1996): The floral biology of the olive: effect of flower number, type and distribution fruit set. - Scientia Horticulturae 66: 149158.

[26] Lebon, G., Douchêne, E., Brun, O., Magne, C., Clément, C. (2004): Flower abscision and inflorescence carbohydrates in sensitive and non-sensitive cultivars of grapevine. - Sexual Plant Reproduction 17: 71-79.

[27] Loussert, R., Brousse, G. (1978): The olive tree. Agricultural techniques and Mediterranean productions. - G. P. Maisonneuve and Larose.

[28] Maire, R. (1933): Studies on the flora and vegetation of the central Sahara. - Memories of the Natural History Society of North Africa, No. 3, Hoggar II Mission. (Maps and planks), Algiers.

[29] Malik, N. S. A., Pérez, J. L. (2011): The effect of high temperature interruptions during inductive period on the extent of flowering and on metabolic responses in olives (Olea europaea L.). - Scientia Horticulturae 129(2): 207-212.

[30] Martins, P. C., Cordeiro, A. M., Rapoport, H. F. (2006): Flower quality in orchads of olive, Olea europaea L., cv Morisa. - Advances in Horticultural Science 20(4): 262-266.

[31] Mukonyi, K. W., Kyalo, N. S., Lusweti, A. M., Situma, C., Kibet, S. (2012): Olea europaea subsp. Cuspidate in Kenya. - African Journal of Biotechnology 11: 8142-8148.

[32] Ouksili, A. (1983): Contribution to the study of the floral biology of the olive tree Olea europaea L. from the formation of the flowers to the effective pollination. - USTL, UnivMontpellier 2, 143p.

[33] Pottu-Boumendil, J. (1989): Electron microscopy: principles and methods of preparation. - INSERM, 221p.

[34] Quézel, P. (1965): The vegetation of the Sahara. From Chad to Mauritania. - Gustav Fisher Verlag, Stuttgart.

[35] Quézel, P. (1978): Analysis of the flora of the mediterranean and Sahara Africa. - Annals of the Missouri Botanical Garden 65: 479-534.

[36] Rapoport, H. F., Rallo, L. (1991): Flower and fruit abscission in Manzanillo olive Olea europaea. - Journal of the American Society for Horticultural Science 116(4): 720-723.

[37] Reale, L., Sgromo, C., Bonofiglio, T., Orlandi, F., Fornaciari, M., Ferranti, F., Romano, B. (2006): Reproductive biology of olive (Olea europaea L.) DOP Umbria cultivars. - Sexual Plant Reproduction 19: 151-161. 
[38] Reale, L., Sgromo, C., Ederli, L., Pasqualini, S., Orlandi, F., Fornaciari, M., Ferranti, F., Romano, B. (2009): Morphological and cytological development and starch accumulation in hermaphrodite and staminate flowers of olive Olea europaea L. - Sexual Plant Reproduction 22(3): 109-119.

[39] Rodrigo, J., Hormaza, J. I., Herriro, M. (2000): Ovary starch reserves and flower development in apricot (Prunus armeniaca L). - Physiologia Plantarum 108: 35-41.

[40] Rodriguez-Garcia, M. I., Fernandez, M. C., Alché, J. D. (1995): Immunocytochemical localization of allergenic protein (Ole e I) in the endoplasmic reticulum of the developing pollen grain of olive (Olea europaea L.). - Planta 196: 558-563.

[41] Rodriguez-Rajo, F. J., Vega-Maray, A. M., Asturias, J. A., Jato, V., Seoane-Camba, J. A., Suarez-Cervera, M. (2010): The relationship between tapetum cells and microspores based on protein localization in Fraxinus angustifolia (Oleaceae) pollen grains. - Journal of Plant Sciences 171(1): 34-52.

[42] Schwendiman, J., Pannetier, C., Michaux-Ferriere, N. (1990): Histology of embryogenic formations during in vitroculture of oil palm (Elaeis guineensisJacq). - Oleagineux 45(10): 409-418.

[43] Serrano, L., Suarez, C., Olmedilla, A. (2008): Structural organization and cytochemical features of the pistil in olive (Olea europaea L.) cv Picual at anthesis. - Sexual Plant Reproduction 21: 99-111.

[44] Serrano, I., Salvatore, P., Adela, O. (2010): Programmed-cell-death hallmarks in incompatible pollen and papillar stigma cells of Olea europaea L. under free pollination. Plant cell reproduction 29: 561-572.

[45] Stephenson, A. G. (1981): Flower and fruit abortion: proximate causes and ultimate functions. - Annual Review of Ecology, Evolution and Systematics 12: 253-279.

[46] Troncoso, A., Prieto, J., Linan, J. (1978): Aclareoquimico of fruits in the Manzanillo de Seveilla olive grove. - Anales de Edafologia y Agrobiologia 37: 882-893. (In Spanish).

[47] Vallade, J. (1999): Structure and development of the plant: Morphogenesis and reproductive biology of angiosperms. - Collection Sciences Sup. Dunod Paris.

[48] Yurukova-Grancharova, P., Davidova, P., Jankova, E., Cantos, M., Linan, J., Troncoso, J., Troncoso, A. (2011): On the gametogenesis and early embryogenesis in some olive tree cultivars. - Flora 206: 47-51. 